\title{
Fractional analysis of Th2-type cytokines in sequential samples of induced sputum
}

\author{
Rame Taha MD, Q Hamid MD PhD, Ron Olivenstein MD
}

R Taha, Q Hamid, R Olivenstein. Fractional analysis of Th2-type cytokines in sequential samples of induced sputum. Can Respir J 2004;11(2):146-150.

BACKGROUND: Recent studies have demonstrated the usefulness of induced sputum in detecting the expression of Th2-type cytokines in asthmatics and have shown that the profile of inflammatory cells in induced sputum differs with time.

OBJECTIVE: To determine whether the duration of sputum induction also affects the expression of Th2-type cytokines in induced sputum.

METHODS: Induced sputum was collected from eight atopic asthmatics at two separated intervals ( 5 min each) during a 15 min sputum induction, and each sample was examined separately for cytokine expression and inflammatory cells. Using immunocytochemistry, interleukin (IL)-4 and IL-5 immunoreactivity, T lymphocytes (CD3), eosinophils (major basic protein), neutrophils (elastase), epithelial cells and macrophages (CD68) were compared in the induced sputum obtained from the $0 \mathrm{~min}$ to $5 \mathrm{~min}$ and the $10 \mathrm{~min}$ to $15 \mathrm{~min}$ samples. RESULTS: The number of immunoreactive-positive cells expressing IL-4 and IL-5 were significantly higher in the 10 to $15 \mathrm{~min}$ induced sputum sample than in the 0 min to 5 min induced sputum sample $(\mathrm{P}<0.05)$. The number of eosinophils was also significantly higher in the $10 \mathrm{~min}$ to $15 \mathrm{~min}$ sample than in the $0 \mathrm{~min}$ to $5 \mathrm{~min}$ sample $(\mathrm{P}<0.05)$. In contrast, the number of neutrophils was significantly higher in the 0 min to 5 min sample than in the 10 min to 15 min sample $(\mathrm{P}<0.01)$; T lymphocytes, macrophages and epithelial cells did not differ between the two samples.

CONCLUSION: This study demonstrates that the duration of sputum induction significantly affects the profile of inflammatory cells and Th2-type cytokine expression, and underscores the need for the standardization of induced sputum procedure.

Key Words: Asthma; Cytokines expression; Induced sputum

\section{L'analyse fractionnelle des cytokines de type Th2 dans des échantillons séquentiels d'expectora- tion induite}

HISTORIQUE : Des études récentes démontrent l'utilité de l'expectoration induite pour déceler l'expression de cytokines de type Th2 chez les asthmatiques et révèlent que le profil des cellules inflammatoires contenues dans l'expectoration induite diffère dans le temps.

OBJECTIF : Déterminer si la durée de l'induction de l'expectoration influe également sur l'expression des cytokines de type Th2 dans l'expectoration induite.

MÉTHODOLOGIE : Une expectoration induite a été recueillie auprès de huit asthmatiques atopiques à deux intervalles (de cinq minutes chacun) pendant une induction de l'expectoration de 15 minutes, et chaque échantillon a fait l'objet d'un examen distinct afin de déceler une expression de cytokines et des cellules inflammatoires. Au moyen de l'immunocytochimie, l'immunoréactivité de l'interleukine (IL-)-4 et de l'IL-5, les lymphocytes (CD3), les éosinophiles (protéine basique majeure), les neutrophiles (élastase), les cellules épithéliales et les macrophages (CD68) ont été comparés entre l'expectoration induite obtenue dans les échantillons de 0 à 5 minutes et ceux de 10 à 15 minutes.

RÉSULTATS : Le nombre de cellules positives à l'immunoréactivité exprimant de l'IL-4 et l'IL-5 était significativement plus élevé dans l'échantillon d'expectoration induite de 10 à 15 minutes que dans celui de 0 à 5 minutes $(\mathrm{P}<0,05)$. Le nombre d'éosinophiles était également beaucoup plus élevé dans l'échantillon d'expectoration induite de 10 à 15 minutes que dans celui de 0 à 5 minutes $(\mathrm{P}<0,05)$. Par contre, le nombre de neutrophiles était grandement plus élevé dans l'échantillon de 0 à 5 minutes que dans celui de 10 à 15 minutes $(\mathrm{P}<0,01)$. Les lymphocytes $\mathrm{T}$, les macrophages et les cellules épithéliales ne différaient pas entre les deux échantillons.

CONCLUSION : La présente étude démontre que la durée de l'induction de l'expectoration influe énormément sur le profil des cellules inflammatoires et sur l'expression des cytokines de type Th2 et souligne l'importance de normaliser la démarche d'expectoration induite.

$\mathrm{B}$ ronchial asthma is a chronic inflammatory disorder that is associated with infiltration of the airway wall with inflammatory cells and upregulation of Th2-type cytokines (1-3). The use of fiberoptic bronchoscopy to obtain bronchoalveolar lavage and endobronchial biopsies has provided a greater understanding of the underlying pathology of asthma $(4,5)$.

Sputum induction is a useful, noninvasive method for collecting airway secretions from asthmatic patients, and analysis of induced sputum for cellular and biochemical constituents has been found to be a valid method of monitoring airway inflammation (6). We have demonstrated that interleukin (IL)-5, IL-4 messenger ribonucleic acid, IL-16, eotaxin and monocyte chemotactic protein-4 immunoreactivity are increased in induced sputum from asthmatic subjects $(7,8)$. Sputum components are

derived from cells that can be found in both the larger central airways and the smaller peripheral airways, and thus, the airway compartment described by induced sputum remains, as yet, not precisely defined. A recent study of the fractional analysis of induced sputum samples obtained sequentially suggests that induced sputum collected early in the course of the sputum induction procedure demonstrates inflammation more consistent with the central airways, whereas induced sputum collected later in the sputum induction procedure reflects inflammation consistent with more distal airways (9). It has also been found that in asthmatics, chronic obstructive pulmonary disease (COPD) patients and healthy subjects, the sputum samples obtained during three consecutive $10 \mathrm{~min}$ inhalation times differ in their cellular and biochemical 
TABLE 1

Clinical characteristics of the study subjects

\begin{tabular}{lcccc}
\hline Subject & Age (years) & Sex & FEV $_{\mathbf{1}}$ (\% predicted) & Serum IgE (U/mL) \\
\hline 1 & 33 & $\mathrm{M}$ & 95 & 630 \\
2 & 30 & $\mathrm{~F}$ & 89 & 850 \\
3 & 29 & $\mathrm{M}$ & 101 & 219 \\
4 & 41 & $\mathrm{M}$ & 97 & 750 \\
5 & 38 & $\mathrm{~F}$ & 80 & 910 \\
6 & 44 & $\mathrm{M}$ & 83 & 790 \\
7 & 39 & $\mathrm{M}$ & 91 & 350 \\
8 & 27 & $\mathrm{~F}$ & 88 & 201 \\
Mean & 35 & - & 91 & 460
\end{tabular}

FEV 1 Forced expiratory volume in $1 \mathrm{~s} ; \mathrm{F}$ Female; IgE Immunoglobulin E; $M$ male

composition $(10,11)$. Therefore, the description of the inflammatory constituents within the airway is dependent on a standardized protocol for sputum induction.

The origins of Th2-type cytokines such as IL-4 and IL-5 include T lymphocytes, eosinophils, neutrophils, mast cells and epithelial cells. Because the quantification of these cellular constituents is dependent on the duration of the sputum induction protocol, it is reasonable to question whether the duration of sputum induction also influences the expression of cytokines in the sputum of asthmatic subjects.

We hypothesized that comparing samples of sputum collected early in the sputum induction procedure with samples of sputum collected later in the sputum induction procedure would demonstrate significant differences in the expression of Th2-type cytokines and in the number of inflammatory-positive cells within the induced sputum of asthmatic subjects. To test this hypothesis, we investigated the expression of IL-4 and IL-5 immunoreactivity, T lymphocytes (CD3), eosinophils (major basic protein [MBP]), neutrophils (elastase), epithelial cells (cytokeratin) and macrophages (CD68) in samples of induced sputum from eight asthmatic subjects obtained from 0 min to 5 min after the onset of sputum induction compared with $10 \mathrm{~min}$ to $15 \mathrm{~min}$ after the onset of sputum induction using immunocytochemistry (ICC).

\section{Subjects}

\section{MATERIALS AND METHODS}

Eight patients fulfilling the American Thoracic Society criteria for asthma (12) and classified as mild asthma were recruited from the Asthma Clinic at the Montreal Chest Institute, McGill University (Montreal, Quebec), and were included in this study. Asthmatic subjects had shown airway reversibility to inhaled beta 2 -agonists or increased airway responsiveness to methacholine (provocative concentration of methacholine producing a $20 \%$ decrease in forced expiratory volume in $1 \mathrm{~s}\left[\mathrm{FEV}_{1}\right]$ less than $8 \mathrm{mg} / \mathrm{mL}$ ). Asthmatic medications included only inhaled, shortacting, selective beta 2 -agonists. Atopy was based on skin test reactivity to a series of common allergens. Clinical characteristics of the subjects are given in Table 1. Asthmatics were nonsmokers, or ex-smokers who had stopped smoking for at least 12 months and had smoked less than five pack-years in their lifetime. Exclusion criteria included the use of inhaled or oral corticosteroids, nonsteroidal anti-inflammatory medications (cromolyn, ketotifen), theophylline, long-acting beta $a_{2}$-agonists, leukotriene antagonists or antihistamines within the three months before the study, the occurrence of a respiratory tract infection in the previous six weeks or immunotherapy in the previous 12 months.

\section{Study design}

The Ethics Review Board of the Montreal Chest Institute, McGill University approved the study, and all subjects gave written, informed consent. The patients were screened by a questionnaire, spirometry and a methacholine inhalation test (if $\mathrm{FEV}_{1}$ was greater than 70\%). Allergy skin prick tests were performed, and atopy was defined as a greater than $3 \mathrm{~mm}$ skin wheal response to one or more of 13 common allergens. Blood was drawn for analysis of complete blood count, and differential and total serum immunoglobulin E. Sputum was induced in the laboratory at least $48 \mathrm{~h}$ after methacholine bronchoprovocation. The difference in $\mathrm{FEV}_{1}$ on the two test days did not exceed $10 \%$.

\section{Sputum induction}

Sputum induction was performed using a modification of the method of Pin et al (6). Subjects were administered salbutamol $(200 \mu \mathrm{g})$ to inhibit possible bronchoconstriction during sputum induction, followed by inhalation of $4.5 \%$ hypertonic saline generated by a DeVilbiss ultrasonic nebulizer (Ultra-Neb 99, Sunrise Medical, USA) with an output of $2.17 \mathrm{~mL} / \mathrm{min}$ (mean particle size $4.14 \mu \mathrm{m}$ ) for $15 \mathrm{~min}$. Procedures were repeated sequentially for 5 min periods unless a fall in $\mathrm{FEV}_{1}$ of greater than $10 \%$ occurred, which resulted in termination of the procedure. The procedure was interrupted every $2 \mathrm{~min}$ to measure peak expiratory flow. Subjects were asked to rinse their mouths and blow their noses to minimize contamination with saliva and postnasal drip, and were also instructed to cough sputum into a sterile container.

\section{Sputum examination}

Sputum sample volumes were recorded. Sputum that was macroscopically free of salivary contamination was selected to minimize squamous cell contamination and was processed within $2 \mathrm{~h}$ by a modification of the technique described by Pizzichini et al (13). Briefly, sputum was selected from the expectorate, and a weighed aliquot was dispersed with four volumes of freshly prepared $0.1 \%$ dithiothreitol followed by four volumes of phosphate buffered solution, after which the dispersed sample was filtered through $48 \mu \mathrm{m}$ nylon mesh. The sample was centrifuged at $300 \mathrm{xg}$ for $10 \mathrm{~min}$. The cell pellet was resuspended in phosphate buffered solution, and the total cell counts of leukocytes and cell viability were determined through the use of trypan blue exclusion. Sputum was obtained from eight atopic asthmatics at two separated intervals, $5 \mathrm{~min}$ each, during a $15 \mathrm{~min}$ sputum induction. Each sample was examined separately for cytokine expression and inflammatory cells. Th2-type cytokine expression and inflammatory cells in the $0 \mathrm{~min}$ to $5 \mathrm{~min}$ induced sputum sample were compared with the $10 \mathrm{~min}$ to $15 \mathrm{~min}$ induced sputum sample. For ICC, cells were adhered to microscope slides using a cytocentrifuge at 650 revolutions/min for $6 \mathrm{~min}$ (Shandon Somerest, United Kingdom); they were then fixed in acetone/methanol (60/40) for $7 \mathrm{~min}$, air dried and stored at $-20^{\circ} \mathrm{C}$ until further use. A sample was considered adequate if, on differential cell counting, the slides contained less than $20 \%$ squamous epithelial cells. To ascertain the immunoreactivity of Th2-type cytokine expression and inflammatory cells, immunohistochemical markers for IL-4 and IL-5, T lymphocytes (CD3), 


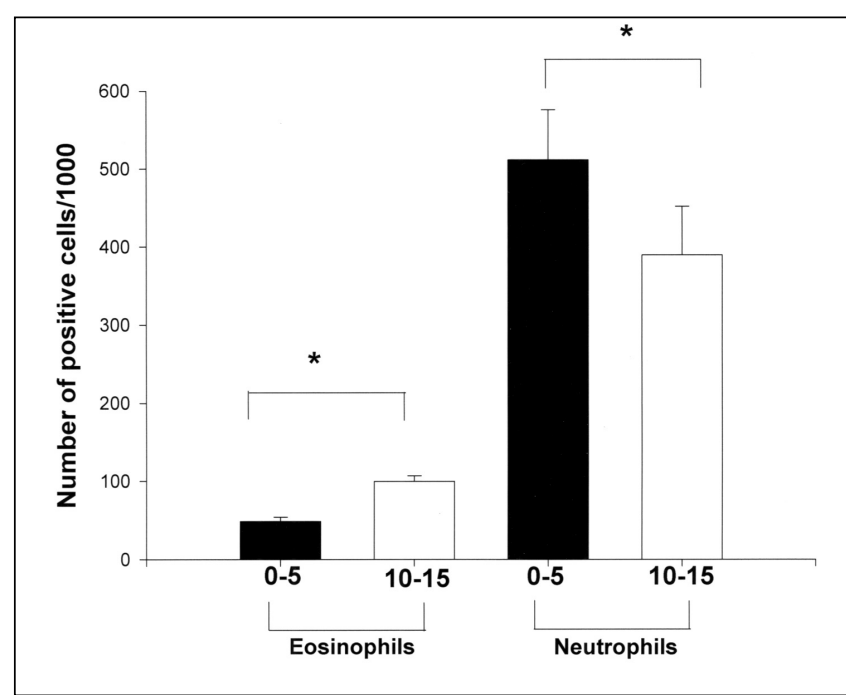

Figure 1) Number of positive cells of eosinophils (major basic protein) and neutrophils (elastase) per 1000 cells counted in $0 \mathrm{~min}$ to $5 \mathrm{~min}$ and $10 \mathrm{~min}$ to 15 min induced sputum samples from asthmatic subjects $(n=8)($ mean \pm SD). $* P<0.05$

eosinophils (MBP), neutrophils (elastase), macrophages (CD68) and columnar epithelial cells (cytokeratine) were used.

\section{Antibodies}

Specific immunohistochemical markers for eosinophils (antiMBP; donated by Dr R Moqbel, University of Alberta, Edmonton, Alberta), T lymphocytes (anti-CD3; Becton Dickinson, Canada), neutrophils (antielastase, Becton Dickinson, Canada), macrophages (anti-CD68; Dako Diagnostic, Canada) and epithelial cells (anticytokeratin, CAM-5.2, a murine monoclonal antibody, Dako Diagnostic, Canada) were used to detect the phenotype of inflammatory cells recovered by sputum induction. Murine monoclonal anibodies were used to detect IL-4 (Genzyme, USA) and IL-5 (donated by Dr J Tavernier, Roche Research, Belgium) immunoreactivity in induced sputum from asthmatic subjects.

\section{ICC}

ICC was performed using a modified alkaline phosphatase-antialkaline phosphatase (APAAP) method as previously reported (14). Briefly, slides were incubated with the specific antibodies overnight at $4^{\circ} \mathrm{C}$. After washing in Tris buffered saline, the secondary antibodies were applied, and the slides were washed in Tris buffered saline and incubated with the APAAP complex. The reaction was visualized by alkaline phosphatase substrate added to fast red TR (Sigma-Aldrich Co, Canada). All of the slides were counterstained with hematoxylin and mounted before examination. Negative control experiments were performed in a similar manner but in the absence of the primary antibody; the primary antibody was replaced by nonspecific mouse immunoglobulin or Tris buffered saline.

\section{Data analysis}

The numbers of positive cell markers of cellular phenotypes were counted per 1000 total cells, excluding squamous cells, with the help of a phase contrast lens. Positive cells were reported as mean \pm SD. To avoid observer bias, slides were coded before analysis

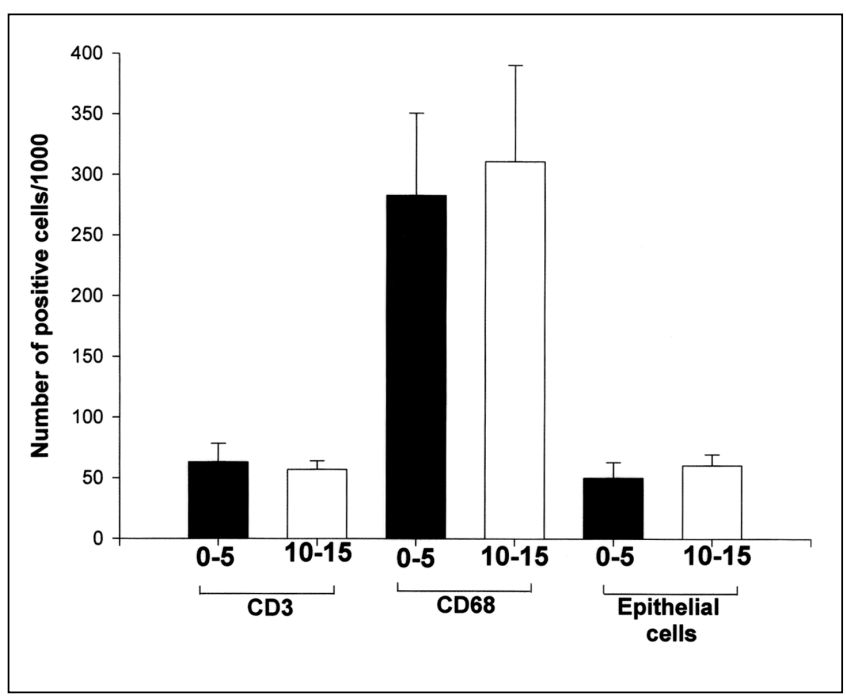

Figure 2) Number of positive cells of $T$ lymphocytes, macrophages and epithelial cells per 1000 cells counted in $0 \mathrm{~min}$ to $5 \mathrm{~min}$ and $10 \mathrm{~min}$ to 15 min induced sputum samples from asthmatic subjects $(n=8)($ mean $\pm S D)$

and read in a blinded fashion. At least two cytospins were counted for each immunocytochemical marker, and the mean value of these slides was reported.

\section{RESULTS}

The total volumes of induced sputum were not significantly different between the early $(2.4 \pm 0.9 \mathrm{~mL})$ and late $(2.1 \pm 1.1 \mathrm{~mL})$ time periods during sputum induction. In addition, the total cell counts were also not significantly different for the early $\left(2 \times 10^{6} / \mathrm{L}\right)$ and late $\left(1.9 \times 10^{6} / \mathrm{L}\right)$ time periods. Cell viability was greater than $85 \%$ in all samples.

\section{Quantification of inflammatory cells in induced sputum}

The number of positive eosinophil cells per 1000 counted cells was significantly greater in the $10 \mathrm{~min}$ to $15 \mathrm{~min}(99.9 \pm 7.1$ cells $)$ than in the 0 to $5 \mathrm{~min}(48.8 \pm 5.3$ cells $)$ induced sputum samples (Figure 1, $\mathrm{P}<0.05$ ), whereas the number of positive neutrophil cells were significantly greater in the $0 \mathrm{~min}$ to $5 \mathrm{~min}$ $(511.9 \pm 64.2$ cells $)$ than in the 10 to $15 \mathrm{~min}(390.2 \pm 62.2$ cells $)$ induced sputum samples (Figure $1, \mathrm{P}<0.05$ ). The number of T lymphocytes, macrophages and epithelial cells per 1000 counted cells did not differ significantly between the 0 min to $5 \min (25.1 \pm 7.7,274.9 \pm 79$ and $25.3 \pm 11.6$ cells, respectively) and $10 \mathrm{~min}$ to $15 \mathrm{~min}(21.2 \pm 8.3,299.9 \pm 79.5$ and $30.3 \pm 10.25$ cells, respectively) sputum samples (Figure 2, Table 2).

\section{Cytokine immunoreactivity in early and late induced} sputum samples

Immunoreactivity for IL-4 and IL-5 was present in the 0 min to $5 \mathrm{~min}$ and the $10 \mathrm{~min}$ to $15 \mathrm{~min}$ induced sputum samples in all subjects, indicating the expression of Th2-type cytokines in inflammatory cells in the airways of mild asthmatics. Omission of the primary antibody or addition of an irrelevant antibody did not result in any specific immunostaining. The number of cells per 1000 counted cells expressing IL-4 was significantly higher in the 10 min to 15 min samples ( $47 \pm 9$ cells) than in the 0 min to $5 \mathrm{~min}$ samples $(32.6 \pm 5.9$ cells) $(\mathrm{P}<0.05)$ (Figure 3$)$. For IL-5, the 
TABLE 2

Cellular characteristics of induced sputum in $0 \mathrm{~min}$ to $5 \mathrm{~min}$ and $10 \mathrm{~min}$ to $15 \mathrm{~min}$ samples from asthmatic subjects

\begin{tabular}{|c|c|c|c|c|c|}
\hline Subject & $\begin{array}{l}\text { T lymphocytes } \\
\text { (cells/1000) }\end{array}$ & $\begin{array}{l}\text { Eosinophils } \\
\text { (cells/1000) }\end{array}$ & $\begin{array}{l}\text { Neutrophils } \\
\text { (cells/1000) }\end{array}$ & $\begin{array}{l}\text { Macrophages } \\
\text { (cells/1000) }\end{array}$ & $\begin{array}{l}\text { Epithelial cells } \\
\text { (cells/1000) }\end{array}$ \\
\hline \multicolumn{6}{|l|}{$0-5 \mathrm{~min}$} \\
\hline 1 & 24 & 51 & 560 & 307 & 11 \\
\hline 2 & 17 & 52 & 510 & 420 & 20 \\
\hline 3 & 39 & 47 & 520 & 170 & 44 \\
\hline 4 & 29 & 42 & 560 & 220 & 34 \\
\hline 5 & 36 & 57 & 590 & 300 & 45 \\
\hline 6 & 19 & 40 & 560 & 273 & 22 \\
\hline 7 & 18 & 53 & 390 & 275 & 18 \\
\hline 8 & 28 & 51 & 440 & 300 & 29 \\
\hline Mean & 25.1 & 48.8 & 511.9 & 274.9 & 25.3 \\
\hline \multicolumn{6}{|c|}{$10-15 \mathrm{~min}$} \\
\hline 1 & 24 & 89 & 320 & 401 & 20 \\
\hline 2 & 25 & 101 & 350 & 307 & 26 \\
\hline 3 & 22 & 110 & 390 & 280 & 50 \\
\hline 4 & 10 & 110 & 410 & 190 & 42 \\
\hline 5 & 20 & 97 & 320 & 320 & 40 \\
\hline 6 & 14 & 95 & 510 & 371 & 25 \\
\hline 7 & 29 & 105 & 460 & 202 & 21 \\
\hline 8 & 39 & 95 & 400 & 417 & 31 \\
\hline Mean & 21.2 & 99.9 & 390.2 & 299.9 & 30.3 \\
\hline
\end{tabular}

number of immunoreactive cells was also significantly higher in 10 min to 15 min samples $(60.54 \pm 6.37$ cells $)$ than in the 0 min to 5 min samples $(39.50 \pm 3.1$ cells $)(\mathrm{P}<0.01)$ (Figure 3$)$.

\section{DISCUSSION}

The present study demonstrates that the number of inflammatorypositive cells and the expression of Th2-type cytokines in induced sputum vary significantly with the timing and duration of sputum induction. There was an increase in the number of eosinophils, as well as in IL-4 and IL-5 immunoreactivity, in the $10 \mathrm{~min}$ to $15 \mathrm{~min}$ samples of induced sputum compared with the 0 min to $5 \mathrm{~min}$ samples. In contrast, neutrophils were significantly higher in 0 min to 5 min samples than in the 10 to 15 min samples. There were no significant differences in the numbers of $\mathrm{T}$ lymphocytes, macrophages and epithelial cells. These results support previous reports that there are differences in the inflammatory cell profile of induced sputum in asthmatics, depending on the time period for sampling, after the onset of sputum induction. These results also demonstrate, for the first time, that the profile of Th2-type cytokines also depends on the conditions of sputum induction.

The precise anatomical compartment from which inflammatory cells found in induced sputum originate is not clearly defined. Sputum consists of tracheobronchial secretions contaminated by saliva, and inflammatory and desquamated epithelial cells. Those same tracheobronchial secretions contain mucus, consisting of products derived from the glands and goblet cells, situated principally in the large airways up to the level of the subsegmental bronchi. They also contain fluids and solutes derived from the bronchiolar and alveolar surfaces, such as surfactant and Clara cells. Indirect evidence supports the

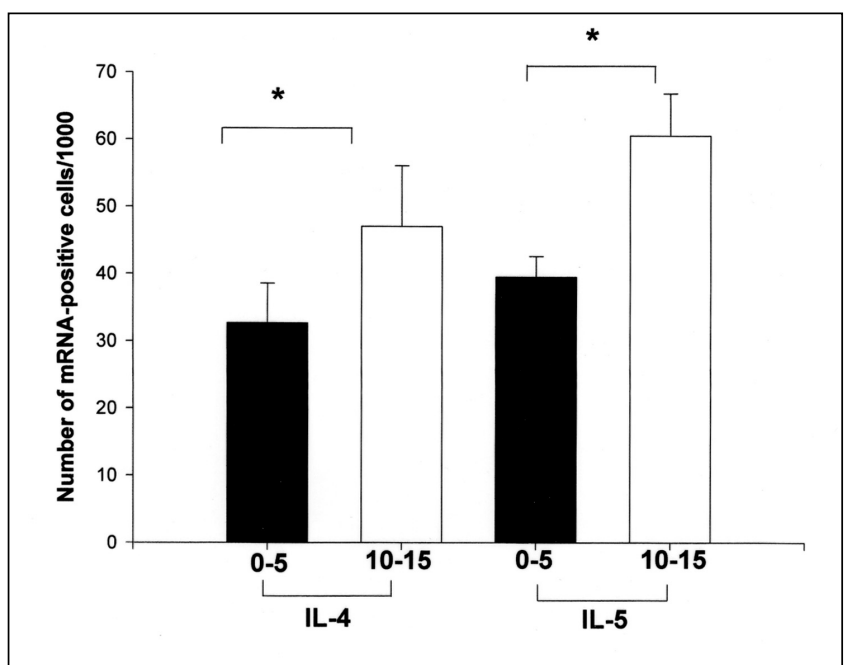

Figure 3) Number of inflammatory-positive cells per 1000 cells counted expressing interleukin (IL)-4 and IL-5 immunoreactivity $0 \mathrm{~min}$ to $5 \mathrm{~min}$ and $10 \mathrm{~min}$ to $15 \mathrm{~min}$ induced sputum samples from asthmatic subjects $(n=8)$ (mean $\pm S D)$. mRNA Messenger ribonucleic acid. $* P<0.05$

notion that induced sputum derives from the central large airways rather than from the smaller peripheral airways. For example, the cellular composition of induced sputum more closely resembles bronchial wash than bronchoalveolar lavage (7). However, markers of alveolar secretions, such as surfactant protein $\mathrm{A}$, can be detected in induced sputum and are increased in the late sputum sample, suggesting that the peripheral airways and alveolar compartments may be represented in induced sputum (9). This same study also found that the cellular and biochemical composition of induced sputum differed between the early and the late sputum samples. Recently, using a radiolabelled aerosol bolus delivery technique, Alexis et al (15) showed that the major site of origin of induced sputum is, in fact, the central airways. Taken together, these findings do suggest that while the cellular composition in induced sputum originates in central airways, there is variability in that cellular composition depending on the duration and timing of the sputum induction procedure.

A previous study using induced sputum in asthmatics by Olivenstein et al (7) demonstrated that the principal cellular sources of IL- 4 and of IL- 5 in the airways are T cells and, to a lesser extent, eosinophils. The increase in the number of IL-4 and IL-5 immunoreactive cells in the $10 \mathrm{~min}$ to $15 \mathrm{~min}$ sputum sample was associated with an increase in eosinophils but not CD3-positive T cells.

Similarly to previous studies, we have demonstrated that the cellular composition of induced sputum changes during the course of the sputum induction procedure. There has been a perception that eosinophils are more prominent in sputum samples collected early in the sputum induction procedure than in those samples collected later in the sputum induction period, but this is most probably due to lack of standardization in the sputum collection procedures. The time periods of sputum collection, the concentration of saline used in the induction process and the techniques to detect the inflammatory constituents have varied in these studies and also differ from that used in the present study. In Gershman et al's (9) study, 
the early time period for collection was from 0 min to $4 \mathrm{~min}$, and they demonstrated $6 \%$ eosinophils compared with the $5 \%$ eosinophils found in our study during the 0 min to $5 \mathrm{~min}$ period. In fact, in Gershman et al, at the 12 min collection time, there was an increase in per cent of eosinophils and in the total eosinophil number, similar to our findings during the $10 \mathrm{~min}$ to 15 min collection period. Holz et al (11) did not show any significant differences in eosinoiphil percentage during three consecutive 10 min sputum induction collection times. While epithelial cells were also increased in the late sputum samples in their study, we found only a mild tendency to an increase in epithelial cells. This may be accounted for by the different time periods used to define early and late sputum, as well as by the different staining techniques used to quantify epithelial cells.

Our findings of an increase in the number of eosinophils and in the expression of IL-4 and IL-5 in the $10 \mathrm{~min}$ to $15 \mathrm{~min}$ induced sputum samples of asthmatic subjects may have diagnostic and therapeutic implications. Because of their importance as inflammatory mediators of airway inflammation in asthma, IL-4 and IL-5 are obvious therapeutic targets for the treatment of allergy and asthma. Indeed, inhibition of IL-4 with soluble IL-4 receptors and the administration of anti-IL-5 monoclonal antibodies have been used as therapeutic strategies in asthma (16-18). Inhaled corticosteroids may attenuate allergic inflammation by inhibition of the synthesis of inflammatory cytokines such as IL-8 and granulocyte macrophage colony stimulating factor (19). Furthermore, using induced sputum in asthmatic subjects, Pizzichini et al (13) suggested that suppres-

\section{REFERENCES}

1. Azzawi M, Bradley B, Jeffery PK, et al. Identification of activated $\mathrm{T}$ lymphocytes and eosinophils in bronchial biopsies in stable atopic asthma. Am Rev Respir Dis 1990;142:1407-13.

2. Laitinen LA, Laitinen A, Haahtela T. Airway mucosal inflammation even in patients with newly diagnosed asthma. Am Rev Respir Dis 1993; 147:697-704.

3. Robinson DS, Hamid Q, Ying S, et al. Predominant Th2-like bronchoalveolar T-lymphocyte population in atopic asthma. N Engl J Med 1992;326:298-304.

4. Kuwano K, Bosken CH, Pare PD, Bai TR, Wiggs BR, Hogg JC.. Small airways dimensions in asthma and in chronic obstructive pulmonary disease. Am Respir Rev Dis 1993;148:1220-5.

5. Wagner EM, Bleecker ER, Permutt S, Liu MC. Direct assessment of small airways reactivity in human subjects. Am J Respir Crit Care Med 1998;157:447-52

6. Pin I, Gibson PG, Kolendowicz R, et al. Use of induced sputum cell counts to investigate airway inflammation in asthma. Thorax 1992; $47: 25-9$

7. Olivenstein R, Taha R, Minshall EM, Hamid QA. IL-4 and IL-5 mRNA expression in induced sputum of asthmatic subjects: Comparison with bronchial wash. J Allergy Clin immunol 1999;103:238-45.

8. Taha RA, Laberge S, Hamid Q, Olivenstein R. Increased expression of the chemoattractant cytokines eotaxin, monocyte chemotactic protein-4, and interleukin-16 in induced sputum in asthmatic patients. Chest 2001;120:595-601.

9. Gershman NH, Liu H, Wong HH, Liu JT, Fahy JV. Fractional analysis of sequential induced sputum samples during sputum induction: Evidence that different lung compartments are sampled at different time points. J Allergy Clin immunol 1999;104:322-8.

10. Richter K, Holz O, Jorres RA, Mucke M, Magnussen H. Sequentially induced sputum in patients with asthma or chronic obstructive pulmonary disease. Eur Respir J 1999;14:697-701. sion of IL-5 production after treatment with inhaled corticosteroids correlated significantly with a reduction in the proportion of eosinophils. A recent report suggests that IL-4 and IL-5 expression is more significantly attenuated in late sputum samples by inhaled corticosteroids designed to favour more peripheral deposition within the airways and is associated with a more significant increase in lung function measurements (20). Thus, sequential sampling of induced sputum may be a useful method to study the anti-inflammatory activity of novel asthmatic therapies.

\section{CONCLUSION}

The present study demonstrated that there is a differential expression of IL-4 and IL-5 immunoreactivity and eosinophils within sequentially collected samples of induced sputum in mild asthmatics. This study provides further evidence that the methodology of sputum induction influences the quantification of the cellular composition and of the inflammatory mediators. These findings underscore the need for standardization of the sputum induction technique if induced sputum is to be a useful medium for the measurement of therapeutic responses.

ACKNOWLEDGEMENTS: The authors thank Ms Elsa Schotman and Ms Cathy Fugère for technical assistance. Merck Frosst Canada Ltd and the Réseau en Santé Respiratoire du FRSQ are acknowledged for financial support. This study was supported by the JT Costello Memorial Research Fund, the Medical Research Council of Canada and Inspiraplex.

11. Holz O, Jorres RA, Koschyk S, Speckin P, Welker L, Magnussen H. Changes in sputum composition during sputum induction in healthy and asthmatic subjects. Clin Exp Allergy 1998;28:284-92.

12. Standards for the diagnosis and care of patients with chronic obstructive pulmonary disease (COPD) and asthma. Am Rev Respir Dis 1987;136:225-44.

13. Pizzichini MM, Pizzichini E, Clelland L, et al. Sputum in severe exacerbations of asthma: Kinetics of inflammatory indices after prednisone treatment. Am J Respir Crit Care Med 1997;155:1501-8.

14. Frew AJ, Kay AB. The relationship between infiltrating CD4+ lymphocytes, activated eosinophils, and the magnitude of the allergen-induced late phase cutaneous reaction in man. J Immunol 1988;141:4158-64.

15. Alexis NE, Hu SC, Zeman K, Alter T, Bennett WD. Induced sputum derives from the central airways: Confirmation using a radiolabeled aerosol bolus delivery technique. Am J Respir Crit Care Med 2001;164:1964-70.

16. Flood-Page PT, Menzies-Gow AN, Kay AB, Robinson DS. Eosinophil's role remains uncertain as anti-interleukin-5 only partially depletes numbers in asthmatic airway. Am J Respir Crit Care Med 2003;167:199-204.

17. Barnes PJ. Cytokine modulators as novel therapies for airway disease. Eur Respir J Suppl 2001;34:67S-77S.

18. Borish LC, Nelson HS, Corren J, et al, IL-4 Asthma Study Group. Efficacy of soluble IL-4 receptor for the treatment of adults with asthma. J Allergy Clin Immunol 2001;107:963-70.

19. Inoue H, Aizawa H, Fukuyama S, et al. Effect of inhaled glucocorticoid on the cellular profile and cytokine levels in induced sputum from asthmatic patients. Lung 1999;177:53-62.

20. Taha R, Hauber HP, Migoumov V, et al. Effect of QVAR on inflammatory cells and cytokine gene expression in early and late sputum samples in asthmatics. Eur Respir J 2003;22 (Suppl 45). (Abst) 


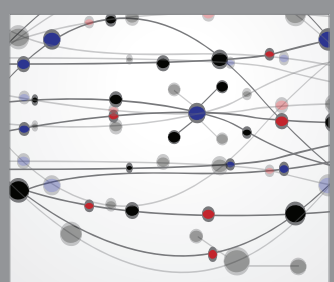

The Scientific World Journal
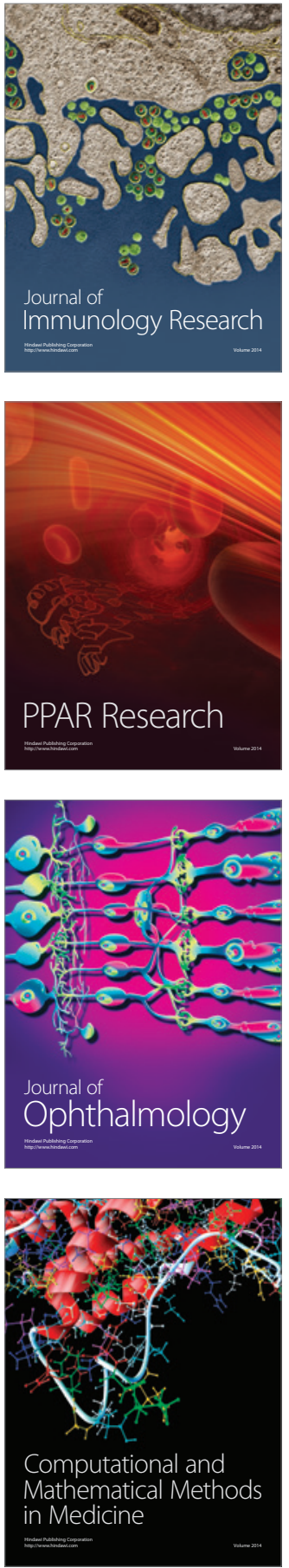

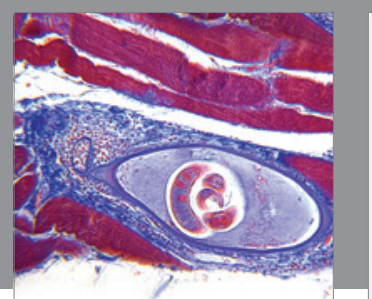

Gastroenterology Research and Practice

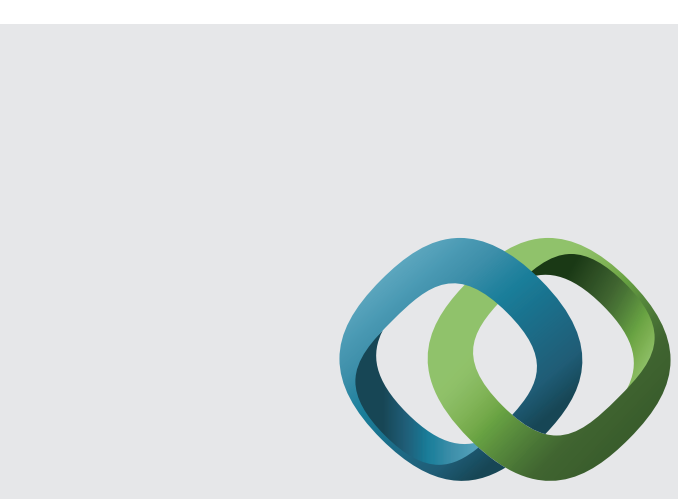

\section{Hindawi}

Submit your manuscripts at

http://www.hindawi.com
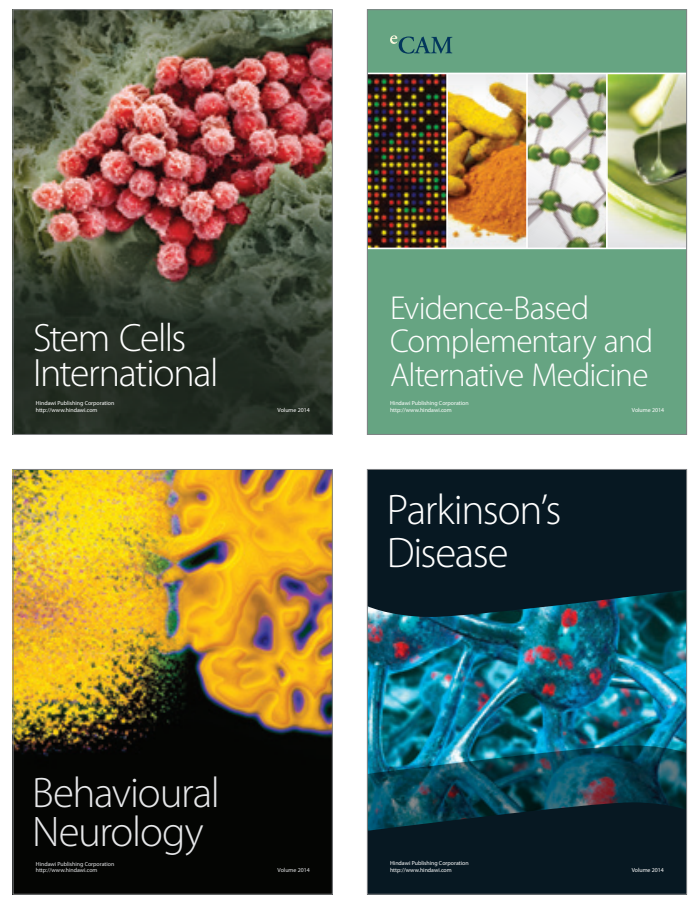
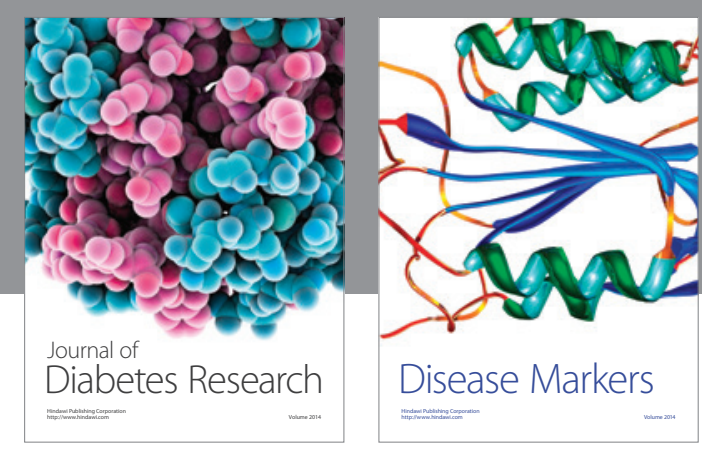

Disease Markers
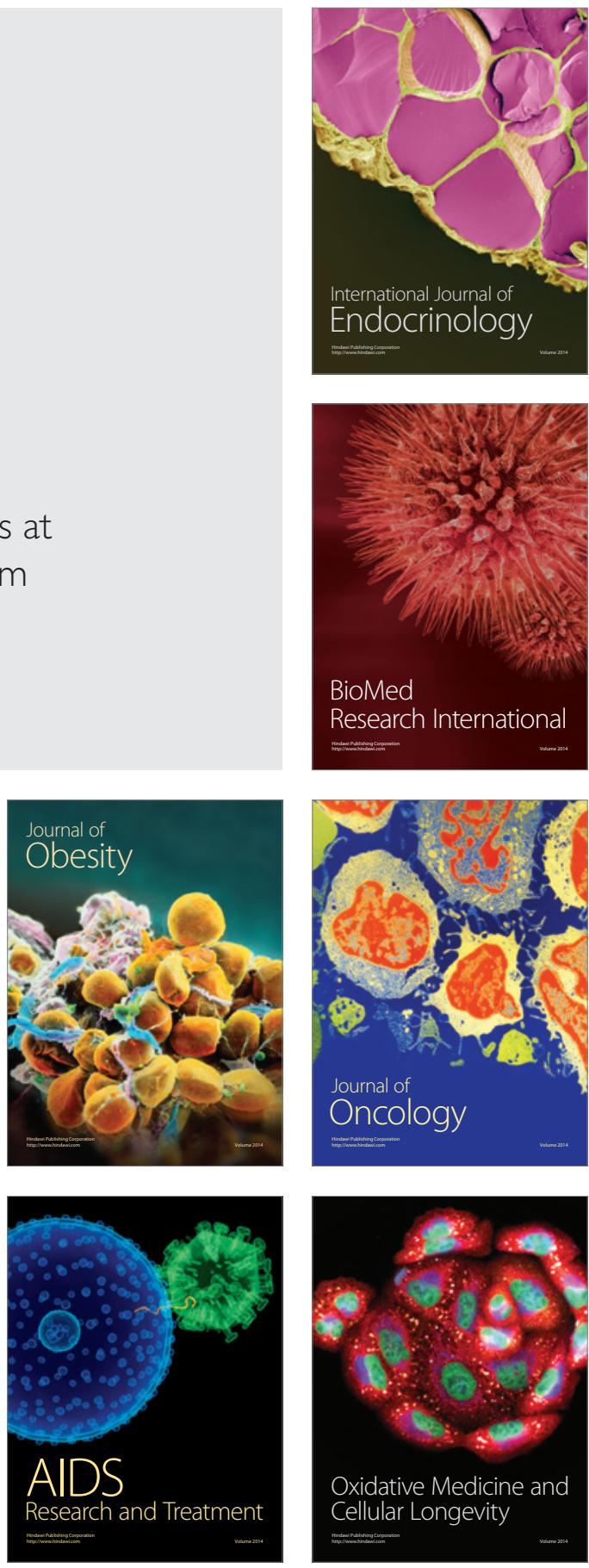